\title{
A Bridge Between Human and Labour Rights: The Concept of Decent Work
}

\begin{abstract}
Sabrina Fetá
sabrina.grivet@gmail.com

PhD Student in Labour Relations. Scuola Internazionale Di Dottorato di Ricerce in Relazioni dei Lavora: Fondazione "Marco Biagi!, Universidade de Modena e Reggio Emilia - Modena - Italia
\end{abstract}

Recebido em 17/09/2011 Aprovado em 23/02/2012

\section{Resumo}

Este artigo dispõe-se a sublinhar os

conceito de trabalho decente, ampliem-se aspectos fundamentais do conceito de os direitos humanos ao direito do trabalho, trabalho decente, tal como elaborado pela Organização Internacional do Trabalho em 1999 que desde aquele tempo tem usado como principal instrumento e objetivo das estratégias de desenvolvimento de emprego e de melhoria das condições de trabalho em termos supranacional.

interpretando-os de uma maneira específica e compatível com seus princípios.

\section{Palavras-chave}

Direito do trabalho. Organização Internacional do Trabalho. Direitos no trabalho. Trabalho relacionados com os direitos humanos. Trabalho decente. 


\title{
Uma ponte entre direitos humanos e direito ao trabalho: o conceito de trabalho decente
}

\author{
Sabrina Fetá
}

Abstract

The paper aims at underlining the concept of decent work, as elaborated by the International Labour Organization in 1999 and since then put forward as leading tool and primary goal of supranational employment strategies. The concept is analysed through the reference to its founding values, basic principles, main problems, strategies to be adopted and goals to be achieved. In the final part of the article, attention will be given to the effective promotion of decent work in two radically different regions of the world: Africa and the European Union.

The central dimension of decent work which is bighlighted is the possibility of extending the meaning of human rights up to the field of labour. Indeed, the content and the evolution of the concept of decent work show that - even beyond the traditional range of labour-related rights - human rights themselves have to be declined in a labourcompatible, labour-centred way.
Key words

Labour Law. International Labour Organization. Rights at work. Labour-related human rights. Decent work. 


\section{Summary}

1 International Labour Organization and development of workers' rights

2 The concept of decent work and its founding values

2.1 Freedom

2.2 Equity

2.3 Security

2.4 Human dignity

3 Decent work: principles, strategies and goals

3.1 Rights at work

3.2 Employment

3.3 Social protection

3.4 Social dialogue

4 Different patterns of decent work

4.1 Africa: decent work for decent life

4.2 European Union: beyond decent work?

Conclusive remarks

References 


\section{International Labour Organization and development of workers' rights}

Since the very beginning of its existence and activity, the International Labour Organization (ILO) has paid central attention to every issue related to the protection of workers.

In 1919, at the moment of the ILO's inception, the world had just been quaked by a global war and survived threatened by revolution, poverty and starvation. There is no doubt the first concern of the new-born Organization was the basic protection of workers against the possible abuse and misuse of power carried out by enterprises.

One of the first Conventions, immediately adopted in 1919 (No. 5), was the Minimum Age Convention, which prohibited child labour in all industrial enterprises. Some years later, in 1930, Convention No. 29 condemned forced or compulsory labour. These prohibitions aimed at guaranteeing a very basic hard-core of workers' rights, which nevertheless was not taken for granted at the time. ${ }^{1}$

After the Second World War, a new generation of workers' rights emerged a central issue of ILO's principal concern: not just the mere prohibition of those forms of work which humiliate the dignity and threaten the health and safety of the person, but the proactive promotion of better forms of workers' rights. Among the Conventions of this group, it is worth to remember those concerning the guarantee of collective labour rights (No. 87/1948 on freedom of association and No. 98/1949 on collective bargaining), and those fostering gender equality and non-discrimination in respect of employment and occupation (No. 100/1951 and No. 111/1958).

New path-choices and new needs of responses and solutions have always conducted the ILO concerning the end of global wars: after the First World War the ILO was founded, it started a new way of rights' creation and promotion. The end of the Cold War in 1989 raised a globalized, competitive world, in which national boundaries rapidly lost most of their sense and consequently national law abandoned most of its power. ${ }^{2}$

1 It is worth to remember that even these core-rights are still nowadays difficult to be protected: the ILO had to rule again on forced labour in 1957 (Convention No. 105) and against child labour both in 1973 (Convention No. 138) and in 1999 (Convention No. 182), urging Member States to the immediate elimination of the worst forms of this abuse.

2 See SOMAVIA, Juan. Report of the Director-General, 87th International Labour Conference, 1999. www.ilo.org 
This context - where most developing countries used their low-cost workforce as competitive advantage and on the other side industrialized countries coudn't impose worldwide their labour standards and acquis - challenged every social worker, from multinational enterprises to workers' associations, from States to supranational institutions.

The ILO itself decided to bet on a new concept, capable of expressing both the hard-core dimension of workers' rights and the flexible promotion of new forms of protection. Moreover, one of the central concerns of the ILO was the achievement of a real and positive labour-related meaning of human rights, both preserving the universality of the human rights agenda and promoting its effective conversion into the labour dimension.

\section{The concept of decent work and its founding values}

In 1999, in the frame of the 87th International Labour Conference, DirectorGeneral Juan Somavia expressed the preoccupation of every worker in times of changes, insecurity and lack of common interests among traditional labour actors, declaring once again that "the mission of the ILO is to improve the situation of human beings in the world of work". "The definition of a clear, common purpose is the first step" continued Somavia, establishing this main purpose and "primary goal of the ILO today" as the promotion of "opportunities for women and men to obtain decent and productive work, in conditions of freedom, equity, security and human dignity". ${ }^{3}$

It is worth to consider at first the four founding values of the concept of decent work, as declared by Somavia, before continuing the analysis of the most challenging points of this speech. As already mentioned, the first aim of the inception of the concept of decent work seems to be the effective transfer into the labour dimension of the human rights agenda - efficaciously summarized through the declaration of these four founding values - not barely reported in its content, but adapted to the specificity of the human being who is engaged in a work activity.

\subsection{Freedom}

Freedom related to work, employment and occupation necessarily entails one of the traditional concerns of the ILO since its first inception: the prohibition of forced labour. The concept of forced labour is nevertheless not so easy to be defined.

3 SOMAVIA, Juan. Report of the Director-General, 87th International Labour Conference, 1999, 2. www.ilo.org 
Convention No. 29/1930 admits that forms of compulsory labour exist in all countries and are often considered acceptable, for reasons of training, education or public necessity. The core difference between these acceptable forms of compulsory labour and the prohibited forms of slavery-type forced labour is that the first and not the latter "is imposed with the consent of the people following democratic procedures". 4

As further elaboration of this border-line feature, Convention No. 105/1957 expressly prohibits all forms of forced labour imposed as means of political coercion, economic development and racial, social or religious discrimination.

As far as labour freedom is concerned, child labour must be considered the same as forced labour and submitted to even stronger condemn: the guarantee of freedom for children and young people under the age of 14 implies that they do not have to be involved in the world of work, since they ought to develop their skills and objectives through education and leisure.

Child labour is degrading to the well-being of children at first, since in most developing countries they are often exploited in unhealthy environments such as factories and mines or, in the worst cases, in illicit traffics and armed conflicts; its widespread is also harmful to the countries and to their future perspectives, since a low-level, undereducated workforce undermines the possibility of real economical development. ${ }^{5}$

This "prohibition dimension" of freedom related to work is of central importance in the developing of the world, whilst industrialized countries face a new, positive dimension of labour-freedom: the freedom for every man and woman to choose their own occupation following their skills, aspirations, aims and educational training. The full guarantee of this freedom is still far away to be achieved.

\subsection{Equity}

The equity or equality principle, from a judicial point of view, has a multilevel meaning: first of all formal equality towards the law, which should be applied to every person in the same way; secondly, substantial equality, which allows different applications of the same law to people subjected to different situations and qualified by different features; thirdly, equality in the law, which

4 GHAI, Dharam. Decent work: concept and indicators. International Labour Review, 2/ 2003, 125

5 See GHAI, Dharam. Decent work: concept and indicators. International Labour Review, 2/2003, 126 
prohibits the lawmaker himself to consider differences like race, gender, religion or nationality as relevant in the law-making procedures. ${ }^{6}$

The balance between the first and the third meaning on one side and the second one on the other side is not easy to be achieved, especially in the field of labour. Lawmakers are often compelled to "discriminate" some workers to the advantage of the weaker ones, promoting rules which do not apply to everybody at the same conditions.

Moreover, in the opinion of the ILO, equality in the field of work should be seen not only as a right to be crystallized and as a static guarantee, but furthermore as an aim, a fundamental objective which should be obtained with a positive development both on national and international level. ${ }^{7}$

The first step to be consolidated is nonetheless the elimination of every form of discrimination related to work and occupation.

"Discrimination at work involves the denial of equality of treatment and opportunity to individuals in their own right or as members of a social group": 8 the ILO expressed its concern about this central topic through Convention No. 111/1958, condemning any type of preference, distinction, inclusion, exclusion or prohibition which, as a result, "has the effect of nullifying or impairing equality of opportunity or treatment in employment or occupation".

The central topic to be underlined within this principle is gender-discrimination in employment and occupation: disparities are in most cases difficult to be highlighted, since in practically all countries the amount of work done by women in children and elders' care, family healthcare and housekeeping remains unknown and unmeasurable and therefore cannot be effectively ruled.

Another problematic topic is the equality of treatment and opportunity for both citizens and foreign workers: non-citizens are often required for special skills, insurances and permissions to be allowed to work in a foreign country's territory. Moreover, it is quite difficult to guarantee to international workers the same social security rights which cover national workforce.

6 See SUPIOT, Alain. Azione normativa e lavoro decente. Prospettive nel campo della sicurezza sociale. Giornale di diritto del lavoro e delle relazioni industriali, 4/2006, 644

7 See the ILO Philadelphia Declaration, 1944. www.ilo.org

8 GHAI, Dharam. Decent work: concept and indicators. International Labour Review, 2/2003, 126

9 ILO Philadelphia Declaration, 1944, Article 1, para. 1(a) www.ilo.org 


\title{
2.3 Security
}

This principle refers to one of the four strategical objectives of the ILO itself, which will be taken into consideration below (see $₫ 3.3$ ): social security and social protection.

As a sort of introduction, it is worth to highlight one of the traditional statement carried out by the ILO from its inception: one of the basic workers' rights is the conviction of not being abandoned in case of impossibility of earning an income, reduction of work capacity or lack, either temporary or definitive, of work energy.

This security means indeed

\begin{abstract}
"protection against vulnerability and contingency. As it is concerned with the human condition of work, the ILO has the responsibility to address the vulnerabilities and contingencies which take people out of work, whether these arise from unemployment, loss of livelihood, sickness or old age." 10
\end{abstract}

\subsection{Human dignity}

The principle of human dignity is closely related to both the principles of security and freedom. The concept of human dignity entails the minimum guarantee of physical and economical security for every man and woman. Without this protection, every other right is impossible to foster, since the lack of the basic, material well-being of humans lead them to the contemning of any other right.

The Universal Declaration of Human Rights immediately affirms that all men and women are equal in dignity, ${ }^{11}$ because the dignity of all the members of the human family is the only fundamental of freedom, justice and peace.

Human dignity means the right to the integrity of human person, which is the incarnation of humanity itself and must always be treated as a goal and never as a means to achieve other purposes. This statement likely obliges business science to reconsider the concept of the worker as productive means among others - who has to adapt himself to the needs and the strategy of the enterprisxe - and consequently leads to an opposite anthropocentric conception of economy itself.

Another aspect of human dignity is closely related to the concept of work and occupation: human dignity is boosted if the worker receives an income linked and

10 SOMAVIA, Juan. Report of the Director-General, 87th International Labour Conference, 1999, 3. www.ilo.org

11 See UN Universal Declaration of Human Rights, 1948, Art. 1, www.un.org 
proportionate to his/her effective activity. Forms of charity and benefits disconnected from any form of contribution of the recipient humiliate capacity and work energy, making future perspectives of occupation less attractive. ${ }^{12}$

\section{Decent work: principles, strategies and goals}

Some years after the 1999 Conference, Juan Somavia sketched the fundamental points of the reasoning which had led the ILO to the elaboration of the concept of decent work.

First of all, work cannot be reduced to productive factors among others, or to a ware that can be sold, bought and exchanged, because work is first of all one of the expressions of human being and human dignity.

It could be said that work is (better be) a source of dignity, identity, development and realization for every human being: through everyone's occupation, societies and countries obtain prosperity and success.

Correctly, it has been highlighted that work should be a source of dignity and realization but it not frequenthy. Therefore the raise of an all-embracing, multilevel concept of positive kind of work, defined as "decent". The choice of such a broad-meaning term aims on one side at comprehending traditional prohibitions, new rights-promotion, old principles and new objectives and on the other side at creating a flexible concept, capable of being interpreted, applied and fulfilled in accordance to the culture, the necessities and the concrete situation of the country in which it is invoked. ${ }^{13}$

As far as mere etymology is concerned, the term "decent" reminds of a situation which is not shameful or humiliating but, on the contrary, generates satisfaction and fulfilment. A proposed synonym of "decent work" is the term "occupation", opposite to "work", both considered in their original, etymological difference. The term "occupation" refers indeed to a complex activity, which requires intellectual, creative and physical ability to be carried out; on the contrary, the Latin etymology of "work", still presented in Roman languages and in the word "labour", is "labor", which refers to fatigue, pain and worries. ${ }^{14}$

12 See SUPIOT, Alain. Azione normativa e lavoro decente. Prospettive nel campo della sicurezza sociale. Giornale di diritto del lavoro e delle relazioni industriali, 4/2006, 637f.

13 See SOMAVIA, Juan. The ILO Decent Work Agenda as the aspiration of people: the insertion of values and ethics in the global economy. PECCOUD, Domininique. Philosophical and spiritual perspectives on Decent Work, Geneva, 2004, 5ff.

14 See STANDING, Guy. Global labour flexibility: seeking distributive justice, UK, 1999 
Consequently, only the term "occupation" could be etymologically harmonious to the definition of decent work and the goals of the ILO could be achieved only through the global "transformation of work into occupation". ${ }^{15}$

Since the inception of the concept of decent work, the ILO made clear how much this principle represent both the perfect synthesis of the traditional mission of the Organization and the starting point for the positive solution of new, challenging problems. ${ }^{16}$

\begin{abstract}
"Decent work means productive work in which rights are protected, which generates an adequate income, with adequate social protection. It also means sufficient work, in the sense that all should have full access to income-earning opportunities. It marks the high road to economic and social development, a road in which employment, income and social protection can be achieved without compromising workers' rights and social standards. Tripartitism and social dialogue are both objectives in their own right, guaranteeing participation and democratic process, and a means of achieving all the other strategic objectives of the ILO." 17
\end{abstract}

This complex, comprehensive definition shows clearly that the four traditional pillars - rights at work, employment, social protection and social dialogue - of the whole ILO's mission, carried out since 1919, are connected to each other, entailed and summarized in the concept of decent work.

\title{
3.1 Rights at work
}

"One of the hallmarks of the twentieth century has been the promotion of human rights. The ILO has made a major contribution to this process, but it needs to concentrate its efforts and to explore fresh approaches." ${ }^{18}$

The pillar of rights at work is the logical antecedent of the other three pillars, since it sets up the ethical basis of the concept of decent work. The first dimension highlighted by the ILO's definition is the one of rights connected to work, which

15 MAREE, Johann. Il "lavoro decente" e la piena occupazione in Africa: una sfida aperta. Diritto delle Relazioni Industriali, 3/2008, 629

16 See MASSIMIANI, Clemente. Flexicurity and decent work in Europe: can they co-exist?. Working Papers Centro Studi di Diritto del Lavoro Europeo “Massimo D’Antona”, 65/2008, 2. www.lex.unict.it

17 SOMAVIA, Juan. Report of the Director-General, 87th International Labour Conference, 1999, 7. www.ilo.org

18 SOMAVIA, Juan. Report of the Director-General, 87th International Labour Conference, 1999, 8. www.ilo.org 
are part of the more general human rights agenda, established by the Universal Declaration of Human Rights in 1948. ${ }^{19}$

An effective relationship is sketched between work as human activity and some of the most important human rights such as dignity, equality, freedom, fair pay, social security and social participation. These matters have been the main object of the core ILO conventions, establishing a range of human rights in close connection to work and occupation.

With regard to monitoring Member States' compliance to the promotion of rights at work in the frame of the decent work agenda, the ILO has elaborated some basic indicators: the diffusion of forced and child labour with regard to individual freedom, the presence of discrimination at work with regard to equality and the effectiveness of workers' associations and organizations in respect of collective freedom. ${ }^{20}$

There are naturally some basic indicators of human rights protection which are also relevant to the labour dimension and this is the reason why a close cooperation among the ILO, the United Nations, regional institutions such as the European Union and the so-called Non-Governmental Organizations must be of central concern for promoting the effective dimension of human rights in developing or weakdemocratic countries. $^{21}$

The first issue attached to any rights-recognition is the definition of the subjects who are entitled to those rights. The 87th International Labour Conference represents a significant change of perspective also with regard to this topic.

The ILO admitted that it had so far concentrated its action on the traditional figure of worker: the Ford-style factory male wage-breadwinner. As the expression itself explains, the traditional dimension of rights at work was strictly connected to the status of wage-workers in the formal economy.

The global modifications of the last decades have opened new scenarios: selfemployed people who are as weak or even weaker than wage-workers, developing countries where formal economy represents only a minor percentage of internal product activities and informal economy is the only alternative to poverty.

19 See MASSIMIANI, Clemente. Flexicurity and decent work in Europe: can they co-exist? Working Papers Centro Studi di Diritto del Lavoro Europeo "Massimo D’Antona", 65/2008, 3. www.lex.unict.it

20 See GHAI, Dharam. Decent work: concept and indicators. International Labour Review, 2/2003, $125 \mathrm{ff}$.

21 See FOFFANO, Silvia. Quale sicurezza nei paesi in via di sviluppo? La questione africana nel contesto globale. Diritto delle relazioni industriali, 3/2008, 635 
Therefore the ILO proclaimed its "concern for all workers" and because

"Almost everyone works, but not everyone is employed. Moreover, the world is full of overworked and unemployed people. The ILO must be concerned with workers beyond the formal labour market — with unregulated wage workers, the self-employed, and homeworkers." ${ }^{22}$

The concept of decent work serves as a universal one, as the broadening of ILO's boundaries towards all those subjects and situations that traditionally laid outside the scope and the mission of the Organization. The minimum standards, the general prohibitions and the promoted aspirations entailed in the concept of decent work must cover every man and woman who carry out an activity, regardless of the fact that it is remunerated, regularly disposed by a contract, executed at home or in the frame of an enterprise.

The concept of decent work concerns labour as a matter of the social dimension of individuals and therefore the rights entailed in its definition must be recognized as social rights, irrespective of any labour-related features of the entitled people. ${ }^{23}$

This universal dimension of decent work is not free of problems and questions: in an ideal world, it could be possible to guarantee the full and perfect entitlement of every person to the complete range of labour-related social rights. The real world has to face the problem of limited resources, which allow advantages for a group of people only through the correspondent renounce of another group.

This is the reason why the ILO allows the restriction of rights-enjoyment for workers if necessary to the rights-recognition in advantage of those people excluded from the workforce and the labour market.

This balance is often highly difficult, since sometimes the advantage for nonworking people involves as first step the creation of new jobs and the extension of the dimension of the labour market. In these phases, common in the developing countries, the creation of new jobs necessarily leads to a certain loss of quality and "decency" of the jobs themselves and apparently contradicts the central and already mentioned principle according to which the rights of the individual are never subordinated to other purposes, first of all to economic development. ${ }^{24}$

The solution of this discrepancy is seek to by most authors and by the ILO itself in an effective definition of the second pillar.

22 SOMAVIA, Juan. Report of the Director-General, 87th International Labour Conference, 1999, 2. www.ilo.org

23 See BRINO, Vania. Organizzazione mondiale del lavoro e mercato globale. PEDRAZZOLI, Marcello. Lessico giuslavoristico, vol. 3, Bologna, 2011, 142

24 See MAREE, Johann. Il "lavoro decente" e la piena occupazione in Africa: una sfida aperta.

Diritto delle Relazioni Industriali, 3/2008, 629 


\subsection{Employment}

"Employment is at the core of the ILO's mandate. Without productive employment, the goals of decent living standards, social and economic development and personal fulfilment remain illusory." 25

As core of the ILO's mission, the goal of full employment is also at the core of the decent work agenda. From a global, collective point of view, work is decent only provided that it is decent with regard to the largest amount of people, possibly for everybody. Every man and woman in the world can enjoy a decent work only provided that he or she works and is employed somewhere.

The pillar of employment should not express a generic claim for more jobs, but for better jobs, carried out in respect of the human rights entailed in the first pillar, fairly paid and source of personal development, satisfaction and fulfilment for the workers.

It has been suggested that the goal of "more jobs" already implies the creation of "better jobs": the pillar of employment should be interpreted as "opportunity of employment" and therefore decent work is to be achieved through the massive presence of different opportunities of occupation among which every man and woman in the world can choose according to his or her aspirations, skills and aims. $^{27}$

The ILO itself has sometimes underlined this perspective, declaring that coping with the strategical goal of a decent work for everybody is the very close consequence of the development of productivity and economic growth. ${ }^{27}$

Realistically, the goal of decent work can be achieved only through economic development but economic development can be achieved only through those beginning phases in which workers' rights are necessarily limited or suspended, as happened in the past in the now-industrialized countries and is happening in the present in the now-developing countries.

A confident opinion trusts the labour market itself to be able to create and impose, through the physiological development of competition rules and mechanisms, common principles of "decent work", which can progressively be improved in accordance to positive economic performances. ${ }^{28}$

25 SOMAVIA, Juan. Report of the Director-General, 87th International Labour Conference, 1999, 12. www.ilo.org

26 See SENATORI, Iacopo - TIRABOSCHI, Michele. La sfida dell'occupazione giovanile nel mercato globale tra produttività del lavoro e investimento in capitale umano. Diritto delle Relazioni Industriali, 3/2008, 660ff.

27 See ILO. World employment Report 2004/2005, Geneva, 2006. www.ilo.org

28 See WEBB, Beatrice -WEBB, Sidney. Industrial democracy, London, 1897 
On the contrary, the ILO has always affirmed the necessity of strong institutions, both on local, national and international level, capable of monitoring the labour market actions and of intervening in case of unequal results. ${ }^{29}$

With the shaping of the central dimension of decent work as creation of working opportunities, there is a clear shift from the pillar of employment to a more liquid one, which is usually defined as "employability".

The option between employment and employability as pillar of the decent work agenda involves some important implications at labour-policies level. Employmentcentred strategies will privilege work-policies, directly aimed at increasing the amount of work or the quality of work for certain groups of disadvantaged people; on the contrary, employability-centred strategies will concentrate on occupationpolicies, indirectly purposed in order to increase the global amount of available work within a social-economic system. ${ }^{30}$

The dilemma of the correct shaping of the occupational pillar of decent work, whether employment, employability or quality of employment, is not even unknown in the European Union.

Indeed, both the new Title VIII of the Amsterdam Treaty, incepted in 1997, and the Lisbon Strategy, launched in 2000, identify "the EU objective [...] essentially with the creation of as many jobs as possible, irrespective of their 'quality' ". 31

The establishment of a quantitative-employment-pillar, irrespective of the quality of the created or extended jobs, is part of all the EU documents of the last decade: "to maximise job creation, in particular for the low-skilled, Member States should pursue efforts to reduce the non-wage labour costs for low-wage earners", whilst social benefits should be "an incentive for workers to accept low-paid jobs." 32

29 "The need for institutions and systems for social protection and social dialogue was glaringly revealed by the crisis in Asia. Such institutions had too often been neglected in the era of rapid growth, and their weakness at the moment of crisis impeded adjustment and enterprise restructuring." SOMAVIA, Juan. Report of the Director-General, 87th International Labour Conference, 1999, 4. www.ilo.org

30 See SENATORI, Iacopo - TIRABOSCHI, Michele. La sfida dell'occupazione giovanile nel mercato globale tra produttività del lavoro e investimento in capitale umano. Diritto delle Relazioni Industriali, 3/2008, 668

31 LO FARO, Antonio. Is a decent wage part of a decent job? Answers from an enlarged Europe. Working Papers Centro Studi di Diritto del Lavoro Europeo “Massimo D’Antona”, 64/2008, 8. www.lex.unict.it

EUROPEAN UNION. Jobs, jobs, jobs. Creating more employment in Europe, Report of the Employment Task-Force chaired by Wim Kok, 2003. www.eur-lex.europa.eu

32 EUROPEAN UNION. Jobs, jobs, jobs. Creating more employment in Europe, Report of the Employment Task-Force chaired by Wim Kok, 2003. www.eur-lex.europa.eu 
The general impression one can incur in reading most of EU-documents on labour policies is that the creation of new jobs is considered a value itself and the struggle to achieve better jobs is definitely not worth of it. The quality of jobs is sometimes described as a sort of hindrance to the achievement of full employment, because "even a bad job can contribute to activating labour force participation". ${ }^{3}$

One could argue that in the European Union "bad jobs" do not really exist and the guarantee of those fundamental rights which constitute decent work has been taken for granted for decades. This statement can be fully agreed to, provided that we talk about the 90s' European Community: relatively small, rich and composed of countries very similar to each other in their history, economical development and social acquis.

The enlarged European Union, on the contrary, welcomed countries characterized by young democracies, fragile developing economies and very different levels of social welfare and workers' rights and care.

Until now, the goal of the European Union as far as occupational policies are concerned seems to remain the achievement of high levels of employment and a quantitatively positive performance in job-creation: on the contrary, "responsibility for safeguarding working conditions and improving the quality of work in the Member States primarily rest on national legislation”. ${ }^{34}$ (See also below, $\mathbb{\$}$ 4.2).

\subsection{Social protection}

\footnotetext{
"Everybody — regardless of where they live — needs a minimum level of social protection and income security, defined according to their society's capacity and level of development. This will not happen automatically. Experience has shown that it is insufficient to rely solely on economic and democratic development. Each country must develop through social dialogue a national social protection system that addresses the needs of all its people, particularly those of women and of the excluded groups working in the informal economy." 35
}

33 LO FARO, Antonio. Is a decent wage part of a decent job? Answers from an enlarged Europe. Working Papers Centro Studi di Diritto del Lavoro Europeo “Massimo D'Antona”, 64/2008, 9. www.lex.unict.it

34 EUROPEAN COMMISSION. Green Paper on modernising labour law to meet the challenges of the 21st century, 2006, www.eur-lex.europa.eu

35 SOMAVIA, Juan. Report of the Director-General, 87th International Labour Conference, 1999, 20. www.ilo.org 
Other uncertainty in the balance of the respective roles of labour market and political institutions concerning employment, the ILO declaration is very clear in defining the central mandate of states in ensuring social security and protection to their workers.

Social security must not be confused with various forms of charity, since the first and not the latter is to be set up as a right, to which people are entitled towards public subjects at different levels. As it has been correctly highlighted, social protection differs from charity because it is not free of charge but modelled in accordance to the solidarity principle.

This principle implies that the contribution of every member of a community will return in terms of assistance in case of necessity of any other member of the same group, regardless of any other concern but the situation of need and the connection to that community. ${ }^{36}$

There are two different types of intervention of social security measures: the first one regards those sudden and isolated events which temporarily or definitely hinder the worker's regular capacity of earning an income (sickness, injury, dismissal, maternity); the latter regards the protection of the so-called disadvantaged subjects, whose difficulty in job-engaging and income-earning lays in the status of the person itself (young people, women, long-term unemployed, aged workers, migrants).

Another model of distinction divides social security needs into three categories: basic needs, such as nutrition, water, primary education and health care; contingencies, such as sickness, injury and disability; natural disasters, such as floods, droughts and earthquakes. ${ }^{37}$

In the frame of the pillar of social security the universal vocation of the concept of decent work has a special importance, since people who lay outside the formal labour market and the traditional notion of labour law are those who among all, need the highest level of social protection. ${ }^{38}$

Moreover, in the last decade, a new category of people has emerged, who need special attention to be paid by social security systems: they are the so-called "working poor".

36 See SUPIOT, Alain. Azione normativa e lavoro decente. Prospettive nel campo della sicurezza sociale. Giornale di diritto del lavoro e delle relazioni industriali, 4/2006, 639ff.

37 See GHAI, Dharam. Decent work: concept and indicators. International Labour Review, 2/2003, 124

38 See MAREE, Johann. Il "lavoro decente" e la piena occupazione in Africa: una sfida aperta.

Diritto delle Relazioni Industriali, 3/2008, 630 
Working-poor are those people who are engaged in an occupation and do not suffer any limitation of their income-earning capacity, but whose wage is not sufficient to provide for them and their families the full satisfaction of basic needs.

The problem of the working-poor is that they should lay outside the traditional systems of social protection, since they have a job and they earn an income, but they clearly need some form of aid, capable of ensuring them a decent life together with a decent job. ${ }^{39}$

In the historical perspective, at the beginning of its activity, the ILO adopted the once prevailing model of social insurance, which aimed at protecting workers against a determined list of situations of temporary of definitive vulnerability, in which the worker cannot provide to his or her needs through the earning of an income.

The direction changed in 1944, with the Philadelphia Declaration, which posed at global level the goal of providing for every worker in need a basic income, basic health care and, in general, basic social protection. ${ }^{40}$ This issue is closely related to the recognition of the dignity of every man and woman (see above, $\$ 2.4$ ): without a minimum standard of insurance of well-being, the worker cannot feel free from anxiety towards the future and cannot fully develop his or her personality.

The basic dimension of social security was defined by the ILO in 1952, through Convention No. 102, later enriched and amended by other provisions. ${ }^{41} \mathrm{~A}$ common feature to this range of conventions is the large use of flexibility clauses, which allow Member States to cope with the expressed principles in different ways and through different means and patterns. Despite this opportunity of managing social security standards in a nation-compatible way, a little number of states have so far ratified ILO social security conventions and even where they are ratified, their application and effectiveness are limited. ${ }^{42}$

The concrete measurement of social security standards compliance of states is also difficult, since the data on public expenditure do not say anything about the

39 See LO FARO, Antonio. Is a decent wage part of a decent job? Answers from an enlarged Europe. Working Papers Centro Studi di Diritto del Lavoro Europeo "Massimo D'Antona", 64/2008, 5. www.lex.unict.it

40 See $\int$ III of the ILO Philadelphia Declaration, 1944. www.ilo.org

See also art. 22 of the United Nations Universal Declaration of Human Rights, 1948. www. un.org

41 See Convention No. 118/1962, which declares the equality of national and migrant workers, and Convention No. 157/1982, which sets up an international system of social rights promotion.

42 See SUPIOT, Alain. Azione normativa e lavoro decente. Prospettive nel campo della sicurezza sociale. Giornale di diritto del lavoro e delle relazioni industriali, 4/2006, 626f. 
effectiveness of such expenditure and the real coverage of workers against risks and vulnerability. ${ }^{43}$

Moreover, stringent social needs which urge the state and the security systems to care about them differ deeply from state to state. This is the reason why the dimension of participation of the recipients is essential for building an effective system of social protection: the beneficiaries must be adequately represented in the decision-making processes of social protection strategies, to express their concrete needs and priorities and to design an effective pattern of aided development. ${ }^{44}$ The best form of exercising this participation is probably at trade unions level, in the frame of social dialogue: this topic will be deepened in the next paragraph.

\title{
3.4 Social dialogue
}

\begin{abstract}
"The ILO is a forum for building consensus. Its tripartite structure reflects a conviction that the best solutions arise through social dialogue in its many forms and levels, from national tripartite consultation and cooperation to plant-level collective bargaining. Engaging in dialogue, the social partners also fortify democratic governance, building vigorous and resilient labour market institutions that contribute to longterm social and economic stability and peace." ${ }^{.45}$
\end{abstract}

Social dialogue is a central dimension of democratic societies, since it is the main tool for promoting the effective participation of the stakeholders in decisionmaking processes. Different groups, involved in the effects of the decisions, discuss through a representation scheme the choices made by other private or public actors.

Social dialogue has been developed in the field of labour and occupation since the XIX century and it has been carried out in different forms and at different levels. At the first level, we can talk of social dialogue between employers and employees to achieve some forms of agreement about employment terms and conditions; secondly, social dialogue takes place between the management (not necessarily the employer) and the workers in a participative functioning of the enterprise (perfectly expressed in the so-called "German model"); finally, the highest level of

43 See GHAI, Dharam. Decent work: concept and indicators. International Labour Review, 2/2003, 123

44 See SUPIOT, Alain. Azione normativa e lavoro decente. Prospettive nel campo della sicurezza sociale. Giornale di diritto del lavoro e delle relazioni industriali, 4/2006, 632

45 SOMAVIA, Juan. Report of the Director-General, 87th International Labour Conference, 1999, 24. www.ilo.org 
social dialogue occurs between social partners and public institutions in order to elaborate the new paths of social and economic policy. ${ }^{46}$

It is quite easy to guess how much a traditionally tripartite and social actors-led organization like the ILO rely on the tool of social dialogue, as both a way for resolving conflicts and for elaborating the best solutions to be achieved. ${ }^{47}$

As already underlined, the definition of decent work involves a double participative dimension: first of all, the concept itself must be shaped on the single country's needs and features and this definition may be elaborated only through the representative voice of the local workforce. On the other hand, no kind of occupation is capable of being defined decent but the one in which workers can express their opinion and participate to the decision-making and decision-enforcing procedures.

Moreover, in a proactive ideal of the concept of decent work, the participation of social partners can promote the widespread of the rights connected to it: provided that most countries have not developed an effective ratification of some important ILO conventions, the concern of social partners could extend some minimum standards of work terms and conditions as matter of social bargaining, producing a sort of soft law global frame to rights protection and promotion. ${ }^{48}$

Workers' representative bodies can have different forms, such as committees, informal associations, organizations: therefore one of the basic human rights necessarily related to social dialogue is the freedom of association for workers.

The ILO raises its concern to this topic at the very beginning of its mission, in 1921, with Convention No. 11, which proclaimed the rights for workers to create their own free associations not only for mutual aid and insurance, but furthermore in order to defend their interests and to participate in decision-making processes affecting these interests.

With Conventions No. 98/1949 and No. 154/1981, the ILO extended its scope of protection, spelling out principles and procedures of collective bargaining, conceived as an essential means of workers' rights' protection and promotion. ${ }^{49}$

46 See GHAI, Dharam. Decent work: concept and indicators. International Labour Review, 2/2003, 132

47 See MAREE, Johann. Il "lavoro decente" e la piena occupazione in Africa: una sfida aperta. Diritto delle Relazioni Industriali, 3/2008, 629

48 See SENATORI, Iacopo - TIRABOSCHI, Michele. La sfida dell'occupazione giovanile nel mercato globale tra produttività del lavoro e investimento in capitale umano. Diritto delle Relazioni Industriali, 3/2008, 663

49 See GHAI, Dharam. Decent work: concept and indicators. International Labour Review, 2/2003, 128,133 
Collective bargaining is the procedural scheme - quite different from country to country because closely linked to the specificity of each history and culture - in whose frame social partners and workers' representatives discuss and merge their interests and proposals.

The deep changes occurred in the last two decades have significantly altered the classical scenario of social dialogue and tripartite industrial relations: historical trade unions have lost their social representation "monopoly", whilst spontaneous associations or non-profit organizations have taken advantage of this. ${ }^{50}$ Moreover, the traditional field of social dialogue had been traditionally established at national level, with the aim at influencing national policy-making processes: in the new globalized world, most economical goals and strategies are bargained, proofed and decided at supranational or international level, and the traditional representative bodies have declined much of their power and appeal.

In this new context, the answer of the ILO is towards a real involvement of these new subjects in the challenge of spreading decent work all over the world, using every tool which could appear effective and suitable in the considered situation. ${ }^{51}$

Indeed, each state has specific history, culture, traditions, needs, problems, levels and paths of development. The concept and the promotion of decent work cannot be the same everywhere and as a matter of fact it has not been the same so far.

\section{Different patterns of decent work}

"If globalization creates a number of common themes and challenges, its impact differs across regions because of the diversity of historical, cultural, economic and social contexts. The ILO must address these contexts - and learn from them. There is no unique model or best practice, only comparative experience and good practice. In both the design and delivery of its services, the ILO must demonstrate flexibility and sensitivity to regional and national diversities." 52

This and similar statements endorsed by the ILO resemble the eternal dichotomy between universality of human rights and specificity of local conditions. The concept of decent work and the related rights have to be spread through the whole

50 See FOFFANO, Silvia. Quale sicurezza nei paesi in via di sviluppo? La questione africana nel contesto globale. Diritto delle relazioni industriali, 3/2008, 635

51 See SOMAVIA, Juan. Report of the Director-General, $87^{\text {th }}$ International Labour Conference, 1999, 25f. www.ilo.org

52 SOMAVIA, Juan. Report of the Director-General, $87^{\text {th }}$ International Labour Conference, 1999, 28. www.ilo.org 
world, regardless of state boundaries; nevertheless, the wide term "decent" was chosen to ensure flexibility in its application and promotion. What is decent in Africa or Southern Asia is probably totally different from what is decent in Europe or Northern America: the concerns of a developing, young, poor country have likely nothing to do with the interests of a rich, aged state of old industrialization.

As a mere drafting of such a complex problem it is worth to sketch the past and the future of decent work in two opposite regions of the global scene: Africa and the European Union.

\subsection{Africa: decent work for decent life}

Work situation in Africa is all but rosy: some of the problems are not exclusively related to the employment and occupation issues, since most African countries are affected by endemic difficulties which seriously hinder any perspective of rapid development.

Among the 51 less-developed countries in the world, 42 of them are African: the half of the African population live in conditions of poverty..$^{53}$

Especially in the Sub-Saharan countries, most population live with few dollars a day per person, the HIV-infection is exceptionally widespread even among children, the deficiency of basic health care causes high rates of mortality and low life expectancy, the democratic structures are fragile if not even merely formal, also due to frequent wars and armed conflicts, economy is weak and low-productive and the lack of primary education makes more difficult for men and women to face this tragic situation. ${ }^{54}$

As far as employment and occupation branch is concerned, the first endemic problem is the overwhelming widespread of informal economy: in Sub-Saharan States, $72 \%$ of the total working population is employed outside the formal labour market, in so-called grey or even black activities, and the percentage is even higher with regard to the sole female workforce.

The informal sector is characterized by workers' exploitation, low productivity, low incomes (often below the standard measure of poverty) and total lack of protection: people employed in it get all but decent work. They are entitled neither to

53 See WEISS, Manfred. “Lavoro decente”: prospettive di sviluppo e realizzazione nelle regioni africane. Diritto delle relazioni industriali, 3/2008, 616

54 See, among all, the statistics presented by GHAI, Dharam. Decent work: concept and indicators. International Labour Review, 2/2003, 121ff. And by SENATORI, Iacopo TIRABOSCHI, Michele. La sfida dell'occupazione giovanile nel mercato globale tra produttività del lavoro e investimento in capitale umano. Diritto delle Relazioni Industriali, 3/2008, 653 
basic rights, nor to collective representation, they do not enjoy social protection and do not have any opportunity of development or educational training.

Around 270 millions people in Africa are employed in the agricultural sector, whose features are completely different from rural economy in the Western countries: farming activities are basic, low-productive and merely subsistence-oriented. We are compelled to classify even rural work in Africa as non-decent.

Another category of African workers who do not enjoy the minimum standards of decent work is the large amount of almost-unemployed people: men and women who are not formally unemployed but underemployed, occasionally employed or working-poor.

As conclusive remarks to this data, it is worth to highlight that only $10 \%$ of Sub-Saharan working population is employed in the non-agricultural formal sector: provided that even the inclusion in the formal sector and the carrying out of a nonagricultural occupation does not constitute a plain guarantee of decent work, we are forced to state that the overloading majority of African population lays outside the goals of the ILO. ${ }^{55}$

Despite the difficulty of this situation, some strategies have been elaborated. First of all, it is important to avoid the attempt of merely exporting successful Western models of industrial relations and patterns of development and employment-management into the African reality.

Africa must develop its own paths of growth, social inclusion and decent work, in perfect accordance to the flexibility promoted by the ILO itself.

A first step should be the extension of the scope of labour law, since the excessive fragmentation of the labour market results in the lack of any protection for the workforce. In this frame, the coverage of social protection systems should be extended in order to include those who are employed in the informal economy and to guarantee widespread minimum standards of work decency.

The central role in the achievement of these goals should be played by trade unions or other representative bodies, through a tripartite social dialogue capable of leading to a participative elaboration of common rules: naturally, conflict-resolutions and the enforcement of those rules must be secured at institutional level. ${ }^{56}$

55 See MAREE, Johann. Il "lavoro decente" e la piena occupazione in Africa: una sfida aperta. Diritto delle Relazioni Industriali, 3/2008, 630f. The data are collected in ILO, Global employment trends 2004, Geneva, 2004

56 See WEISS, Manfred. "Lavoro decente": prospettive di sviluppo e realizzazione nelle regioni africane. Diritto delle relazioni industriali, 3/2008, 618f. 
An interesting perspective of development in the problematical African context adopts youth as the starting point and strategical advantage. All African countries are characterized by an incredibly high number of people aged under 25: their perspectives and future expectancies are all but enviable, since their lack of education and the scarce opportunities of their countries will push them either into low-paid, under-qualified jobs or towards out-migration.

The first step should be a massive investment on primary and vocational education for everybody, with a progressive insertion into the labour market of a flexible, trained workforce.

Indeed, effective strategies of education for these young people will gain multiple successes: the creation of better workers, claiming for better jobs, which they can even create on their own, and the general development of their countries, which will foster a virtuous circle of social and economical well-being and therefore the achievement of decent work goals. ${ }^{57}$

\subsection{European Union: beyond decent work?}

The European Union is traditionally considered the most fertile field for coordinated labour strategies at supranational level: moreover, the concern of the institutions for workers' rights, equality, social justice and economic development represents one of the strongest aspects of the EU itself.

The EU has developed its own "decent work agenda" since 2000 (just one year after the "decent work" report in the frame of the ILO), through the promotion of the Lisbon Strategy, aimed at creating more and better jobs, promoting employment, economic well-being and a workers'-rights-compatible development of those tools, which are necessary to face the challenges of the new millennium in the globalized world. ${ }^{58}$

In 2001, EU and ILO officially stated an agreement of cooperation, in order to hint at an alliance between two traditional rights-promoting institutions and address in an integrated way social and employment problems.

In 2006, the European Commission clearly adhered to the decent work agenda, sharing its goals and strategies, and endorsed this decision through the publishing of communication no. 249, titled "Promoting decent work for all. The EU contri-

57 See SENATORI, Iacopo - TIRABOSCHI, Michele. La sfida dell'occupazione giovanile nel mercato globale tra produttività del lavoro e investimento in capitale umano. Diritto delle Relazioni Industriali, 3/2008, 670ff.

58 See EUROPEAN COMMISSION. Social policy agenda, Communication no. 379/2000 
bution to the implementation of the decent work agenda in the world". This communication contains concrete indications on how to promote decent work, through a detailed analysis of goals to be achieved, strategies to be adopted and actions to be taken. ${ }^{59}$

The first aspect, already highlighted in the title of this communication, is that the European Union shapes its concern about decent work issues as an external and not as an internal one. The European Union set up itself as a sort of "ILO's colleague", an international organization whose aim is promoting the decent work agenda throughout the countries of the whole world: but the difference between EU and ILO is that the first and not the latter is itself an union of states, which should be directly interested in the achievement of decent work strategies and goals inside its boundaries. ${ }^{60}$

The reason of this attitude of the EU is explained by the Commission itself: promoting decent work is for Europe a matter of international cooperation and no more of internal policy, since "the Community acquis in the fields of employment, social policy and equal opportunities in many respects goes beyond the international standards and measures which underpin the concept of decent work."' ${ }^{\prime \prime 1}$

Because of the affirmation of this overriding developing of work standards, quality and rights in the frame of the European Union, the institutions draw a difference between the international concern for "decent work" and the internal policy of "good work". The concept of good work (sometimes referred to as "quality of work") raised in 2007 in the frame of the European social partners agreement, ${ }^{62}$ and was meanwhile adopted by the Council, chaired by the German Presidency. ${ }^{63}$

Good work means something more than mere decent work: beyond the basic acquis of sufficient levels of employment, rights-protection, social security and

59 See MASSIMIANI, Clemente. Flexicurity and decent work in Europe: can they co-exist?. Working Papers Centro Studi di Diritto del Lavoro Europeo "Massimo D’Antona", 65/2008, 5ff.. www.lex.unict.it

60 See LO FARO, Antonio. Is a decent wage part of a decent job? Answers from an enlarged Europe. Working Papers Centro Studi di Diritto del Lavoro Europeo "Massimo D’Antona", 64/2008, 2. www.lex.unict.it

61 EUROPEAN COMMISSION. Promoting decent work for all. The EU contribution to the implementation of the decent work agenda in the world, Communication no. 249/2006, www.eur-lex.europa.eu

62 EUROPEAN TRADE UNIONS CONFEDERATION, BUSINNESS EUROPE. Key challenges facing European labour markets: a joint analysis of European social partners, 18.10.2007. www.etuc.org

63 See the conclusions of the informal ministerial meeting, Berlin, 19.01.2007. www.eur-lex.europa.eu 
social dialogue, the European Union aims at boosting high level of quality of work, capable of guaranteeing productivity, free time, life long learning, personal development, conciliation with family life and entrepreneurship.

Despite the fact that most European countries are effectively far beyond the guarantee of bare decency to their workers, the picture drafted by the Commission's communication is probably too idyllic to be true. First of all, the core of the Lisbon agenda was the first inception of the concept of flexicurity, the strategy aiming at combining employment flexibility and security in order to enhance adaptability, full employment and social cohesion in the labour market.

The possible co-existence between flexicurity and decent (or, furthermore, good) work in the European Union raises some important questions: as already mentioned above (see $\int 3.2$ ), the pillar of employment could be interpreted in a lot of different ways and the choice of the European institutions seems to be directed towards employability or "security of a job" more than towards effective employment security ("in a job"). ${ }^{64}$

Moreover, flexibility in recruitment, dismissal, work terms and conditions could seriously undermine the protection of workers' rights and the effectiveness of social dialogue and collective participation in employment-policies-making, since the weaker is the connection between the worker and his or her job, the less is the interest of the worker in unionising or other forms of participation. ${ }^{65}$

The excessive optimism of the Commission's picture of the achievement of decent work in Europe also comes out from the last developments related to Unionenlargement. As already remarked, most of the new Member States of the EU-27 have a completely different history (and thus "labour history") than the traditional development which occurred in the older Member States. Eastern Europe countries, after the collapse of the Soviet Union, adopted patterns of both political, social and economical development which do not always cope with the main directions of EU policies.

Eastern-European countries are characterized by lower level of social protection, social welfare, union density and - most evidently - lower wages. The problem of wage-dumping, put into act by companies from countries which have recently

${ }^{64}$ See EUROPEAN COMMISSION. Towards common principles of flexicurity: more and better jobs through flexibiliy and security, Communication no. 359/2007, www.eur-lex. europa.eu

${ }^{65}$ See MASSIMIANI, Clemente. Flexicurity and decent work in Europe: can they co-exist? Working Papers Centro Studi di Diritto del Lavoro Europeo “Massimo D’Antona”, 65/2008, 17ff.. www.lex.unict.it 
joined EU, is of central concern for most political, economical and social actors. ${ }^{66}$

The relevant difference in life standards and costs, existing among European countries, makes it almost impossible to set common rules about labour wage and non-wage costs, despite the social danger of wage-dumping, which can lead to a progressive reducing of wage levels in all countries - in order to withstand the new ones' competition - with a general loss in terms of work quality, protection, development and productivity: in one word, the danger is the loss of work decency.

Provided the impossibility of affirming general rules about wage levels in the enlarged European Union, the only path to follow seems to be the internal coherence of every single Member State in relating decent work to decent wage on national basis.

In other words, it could be drafted that while the concept of decent work has a necessary supranational potential, the concept of decent wage has to remain a national one. Within the definition of decent work, the component of decent wage has to be defined at national level, in accordance to the State's founding values and constitutional norms.

This could be for example the case of Italy, whose Constitutional Chart entails a norm, Article 36.1, which provides the worker with the right to a "proportionate wage to the quantity and quality of his/her work, sufficient to guarantee the worker and his/her family a free and decent life."

The expressions contained in this norm resemble the formulation of both the human rights and the decent work agendas and show highly positive attitude for promoting the national dimension of decent wage as central part of the supranational dimension of decent work.

\section{Conclusive remarks}

In conclusion of the more times quoted Report, Juan Somavia summarized the aim of such an important speech, declaring that

\footnotetext{
"In short, the proposals contained in this Report constitute a programme of far-reaching reform which seeks to anticipate - rather than react to - the processes of global change today. Inevitably, they raise complex and delicate issues which touch on political sensitivi-
}

${ }^{66}$ See LO FARO, Antonio. Is a decent wage part of a decent job? Answers from an enlarged Europe. Working Papers Centro Studi di Diritto del Lavoro Europeo "Massimo D’Antona", 64/2008, 5ff.. www.lex.unict.it 
ties and institutional cultures. To overcome them will require a shared endeavour and a close partnership between the Office and the constituents. ${ }^{\circ 7}$

The ILO expressed its course of action about decent work at the dawn of the new millennium, more than a decade ago. Time has shown how much the provisions and the aspirations of this agenda are difficult to fulfill: in 1999, social and political actors were worried by the financial crisis in Eastern Asia, nowadays the concern regards a global economic crisis which has already been lasting for nearly three years.

The situation in Africa still presents some slow signals of development and the persistence of deep problems, European Union is fighting against economic stagnation and the anti-European pushing of some of its Members, the colossus of China has powerfully irrupted in the global scene, showing that decent work and successful economic development are difficult to be put forward together. ${ }^{68}$

Despite this complex and multifaceted scenario, and perhaps because of it, conscious political, economical and social actors cannot renounce to the promotion of the global dimension of decent work, remembering that the well-being of men and women remains the only aim of economical development and richness- increasing.

As final remark, it is worth to remember what Pope Benedict XVI correctly highlighted in his social encyclical "Caritas in veritate": the recognition of rights, especially at social and labour level, must be counterbalanced by a strong stress on their symmetrical duties and obligations. ${ }^{69}$

Therefore, the proactive dimension of decent work can be raised only through the concern, the involvement and the care of every worker who aims at enjoying the positive side of labour-connected human rights.

${ }^{67}$ SOMAVIA, Juan. Report of the Director-General, $87^{\text {th }}$ International Labour Conference, 1999, 49. www.ilo.org

68 See SENATORI, Iacopo - TIRABOSCHI, Michele. La sfida dell'occupazione giovanile nel mercato globale tra produttività del lavoro e investimento in capitale umano. Diritto delle Relazioni Industriali, 3/2008, 660

${ }^{69}$ See VALLEBONA, Antonio."Caritas in veritate” e diritto del lavoro. Rivista italiana di diritto del lavoro, I/2009, 444 


\section{References}

BRINO, Vania. Organizzazione mondiale del lavoro e mercato globale. PEDRAZZOLI, Marcello. Lessico giuslavoristico, vol. 3, Bologna, 2011, 137

FOFFANO, Silvia. Quale sicurezza nei paesi in via di sviluppo? La questione africana nel contesto globale. Diritto delle relazioni industriali, 2008, 3, 633

GHAI, Dharam. Decent work: concept and indicators. International Labour Review, 2003, 2, 113

LO FARO, Antonio. Is a decent wage part of a decent job? Answers from an enlarged Europe. Working

Papers Centro Studi di Diritto del Lavoro Europeo “Massimo D’Antona”, 64/2008. www.lex.unict.it

MAREE, Johann. Il "lavoro decente" e la piena occupazione in Africa: una sfida aperta. Diritto delle Relazioni Industriali, 2008, 3, 627

MASSIMIANI, Clemente. Flexicurity and decent work in Europe: can they co-exist?. Working Papers Centro Studi di Diritto del Lavoro Europeo “Massimo D’Antona”, 65/2008. www.lex.unict.it

SENATORI, Iacopo - TIRABOSCHI, Michele. La sfida dell'occupazione giovanile nel mercato globale tra produttività del lavoro e investimento in capitale umano. Diritto delle Relazioni Industriali, 2008, 3, 648

SOMAVIA, Juan. Report of the Director-General, 87th International Labour Conference, 1999. www.ilo.org SOMAVIA, Juan. The ILO Decent Work Agenda as the aspiration of people: the insertion of values and ethics in the global economy. PECCOUD, Dominique. Philosophical and spiritual perspectives on Decent Work, Geneva, 2004

STANDING, Guy. Global labour flexibility: seeking distributive justice, UK, 1999

SUPIOT, Alain. Azione normativa e lavoro decente. Prospettive nel campo della sicurezza sociale. Giornale di diritto del lavoro e delle relazioni industriali, 2006, 4, 625

VALLEBONA, Antonio. “Caritas in veritate” e diritto del lavoro. Rivista italiana di diritto del lavoro, 2009, I, 439

WEBB, Beatrice -WEBB, Sidney. Industrial democracy, London, 1897

WEISS, Manfred. "Lavoro decente": prospettive di sviluppo e realizzazione nelle regioni africane. Diritto delle relazioni industriali, 2008, 3, 615 